\section{Comparison of Pruned and Unpruned Pear Seedlings for Survival and Growth}

\author{
Craig K. Chandler ${ }^{1}$ \\ Ohio Agricultural Research and Development Center, The Ohio State \\ University, Wooster, OH 44691
}

Additional index words. Pyrus, transplanting

Two-year-old, bare-root pear seedlings from the USDA Appalachian Fruit Research Station were planted at the Ohio Agricultural Research and Development Center (OARDC), Wooster, in 1984. Based on visual observation, these seedlings had a larger shoot than root system. Standard practice prescribes that these trees be heavily pruned at planting to bring the shoot into balance with the roots. Zimmerman (1972) noted, however, that there is general agreement among horticulturists that pruning delays flowering of seedling fruit trees. Layne and Quamme (1975) suggested that, for early fruiting of pear seedlings, it is advisable to avoid excessive pruning. The purpose of this work was to determine if pruning at planting does, in fact, improve a seedling's chances of survival and to assess pruning effects on growth. A paired difference experiment was conducted in which 70 pairs of seedlings were

Received for publication 6 Feb. 1989. Salaries and research support provided by state and federal funds appropriated to the Ohio Agr. Res. and Dev. Center, The Ohio State Univ. Journal Article no. 1989. The cost of publishing this paper was defrayed in part by the payment of page charges. Under postal regulations, this paper therefore must be hereby marked advertisement solely to indicate this fact.

'Current address: AREC, Univ. of Florida, 13138 Lewis Gallagher Rd., Dover, FL 33527. chosen from among 1000 planted on 1 May 1984. Paired seedlings were siblings in close proximity to each other. They were similar in original height and trunk diameter. The main stem of one member of each pair was headed back $\approx 50 \%$ at planting; the other member was not pruned. The seedlings were not pruned in 1985. Soil moisture was plentiful during the establishment period; the OARDC weather station recorded rainfall on 17 out of 31 days in May ( $137 \mathrm{~mm}$ of precipitation for the month, compared to the long-term average of $98 \mathrm{~mm}$ ). Tree height and trunk diameter were measured at the end of the first and second growing seasons.

Pruning had no detectable effect on establishment and survival; only one pruned tree and two unpruned trees out of 140 seedlings in the study died during the first growing season. By the end of the second growing season, two more pruned trees and one additional unpruned tree had died.
Pruning did influence growth. In 1984, the pruned seedlings had a greater height increment (i.e., height gain over the season) than did the unpruned seedlings (Table 1). However, the final height of the pruned seedlings was still less than that of those not pruned. These results are similar to those obtained with oak seedlings $(\mathrm{C}$, Whitcomb, unpublished data). Causely (1979), reporting on Whitcomb's research, stated that, after 1.5 years, oak trees pruned back $40 \%$ at planting were still shorter than trees left unpruned.

By the end of 1985, final height and trunk cross-sectional area (TCA) of the pruned seedlings were not significantly different than those of the unpruned seedlings (Table 1). The pruned seedlings again had a greater height increment than the unpruned seedlings, although the difference in height increment between 1984 and 1985 was less for the pruned seedlings.

Shoot pruning of pear seedlings at planting can be a labor-intensive operation, which the results of this experiment indicate may not be warranted.

\section{Literature Cited}

Causley, F. 1979. Thanks, Carl, now what about Mom's apple pie? Southern Florist \& Nurseryman. 22 June. p. 24.

Layne, R.E.C. and H.A. Quamme. 1975. Pears, p. 38-70. In: J. Janick and J.N. Moore (eds.). Advances in fruit breeding. Purdue Univ. Press, West Lafayette, Ind.

Zimmerman, R.H. 1972. Juvenility and flowering in woody plants: A review. HortScience 7:447455 .

Table 1. Effect of pruning on the growth of pear seedlings. ${ }^{2}$

\begin{tabular}{lcccccc}
\hline \hline & \multicolumn{2}{c}{1984} & & & 1985 & \\
\cline { 2 - 7 } & $\begin{array}{c}\text { Height } \\
\text { increment } \\
(\mathrm{cm})\end{array}$ & $\begin{array}{c}\text { Final } \\
\text { ht }\end{array}$ & $\begin{array}{c}\text { Height } \\
\text { increment } \\
(\mathrm{cm})\end{array}$ & $\begin{array}{c}\text { Final } \\
\mathrm{ht}\end{array}$ & $\begin{array}{c}\text { TCA } \\
(\mathrm{cm})\end{array}$ & $\left(\mathrm{cm}^{2}\right)$ \\
\hline Treatment & $63^{*}$ & $128^{*}$ & $7^{*}$ & $205^{\mathrm{Ns}}$ & $9.6^{\mathrm{NS}}$ \\
Pruned & 18 & 162 & 55 & 213 & 10.2 \\
\hline
\end{tabular}

${ }^{2}$ Means within columns separated by Student's t test $(P=0.05)$. 